\title{
Short-term effects of $\beta 2$-AR blocker ICI 118,551 on sarcoplasmic reticulum SERCA2a and cardiac function of rats with heart failure
}

\author{
HAIBIN GONG, YANFEI LI, LEI WANG, QIAN LV and XIULI WANG \\ Department of Cardiology, Xuzhou Central Hospital, Xuzhou Cardiovascular Disease Institute, \\ Xuzhou, Jiangsu 221009, P.R. China
}

Received January 21, 2016; Accepted June 13, 2016

DOI: $10.3892 /$ etm.2016.3450

\begin{abstract}
The study was conducted to examine the effects of ICI 118,551 on the systolic function of cardiac muscle cells of rats in heart failure and determine the molecular mechanism of selective $\beta 2$-adrenergic receptor ( $\beta 2$-AR) antagonist on these cells. The chronic heart failure model for rats was prepared through abdominal aortic constriction and separate cardiac muscle cells using the collagenase digestion method. The rats were then divided into Sham, HF and $\mathrm{HF}+\mathrm{ICI} 50 \mathrm{nM}$ goups and cultivated for 48 h. $\beta 2-\mathrm{AR}, \mathrm{Gi} /$ $\mathrm{Gs}$ and sarcoplasmic reticulum $\mathrm{Ca}^{2+}$-ATPase (SERCA2a) protein expression levels in the cardiac muscle cells were evaluated by western blotting and changes in the systolic function of cardiac muscle cells based on the boundary detection system of contraction dynamics for individual cells was measured. The results showed that compared with the Sham group, the survival rate, percentage of basic contraction and maximum contraction amplitude percentage of cardiac muscle cells with heart failure decreased, Gi protein expression increased while Gs and SERCA2a protein expression decreased. Compared with the HF group, the maximum contraction amplitude percentage of cardiac muscle cells in group $\mathrm{HF}+\mathrm{ICI} 50 \mathrm{nM}$ decreased, the Gi protein expression level increased while the SERCA2a protein expression level decreased. Following the stimulation of $\mathrm{Ca}^{2+}$ and ISO, the maximum contraction amplitude percentage of cardiac muscle cells in the HF+ICI $50 \mathrm{nM}$ group was lower than that in group HF. This indicated that ICI 118,551 has negative inotropic effects on cardiac muscle cells with heart failure, which may be related to Gi protein. Systolic function of cardiac muscle cells with heart failure can therefore be
\end{abstract}

Correspondence to: Dr Haibin Gong, Department of Cardiology, Xuzhou Central Hospital, Xuzhou Cardiovascular Disease Institute, 199 Jiefang Road, Xuzhou, Jiangsu 221009, P.R. China

E-mail: gong_haibin1@163.com

Key words: $\beta 2$-adrenergic receptor, sarcoplasmic reticulum $\mathrm{Ca}^{2+}$-ATPase, cardiac muscle cell, congestive heart failure reduced by increasing Gi protein expression and lowering SERCA2a protein expression.

\section{Introduction}

The $\beta$-adrenergic receptor ( $\beta$-AR) constitutes a $\mathrm{G}$-proteincoupled, catecholamine-mediated receptor that is important in the regulation of cardiac function. The main subtypes of $\beta$-AR in cardiac muscle tissue are, $\beta 1-\mathrm{AR}$ and $\beta 2-\mathrm{AR}$. The distribution, function and effect of the two receptor subtypes in cardiac muscle tissue differ in normal and multiple pathological conditions (1). $\beta 1-\mathrm{AR}$ and $\beta 2-\mathrm{AR}$ are commonly expressed on the surface of cardiac muscle cell membranes and mediate the systolic function of cardiac muscle, but they generate different functions through different signaling pathways $(2,3)$. Under normal physiological conditions, systolic function of the heart is mainly related to $\beta 1-A R$, while the signal system of $\beta 2-A R$ has a weak response to catecholamines. During the development of chronic heart failure (CHF), $\beta 2$-AR plays a key role. For an aged heart in failure, the amount and function of $\beta 1-A R$ decreases, while the amount of $\beta 2-A R$ is not altered, which means that the physiological effects of $\beta 2$-AR can be influenced and improved significantly $(4,5)$.

$\beta$-AR blockers have been widely used in China for the treatment of congestive heart failure (CHF). Through clinical observation, symptoms are improved, quality of life is increased and the mortality rate decreases after long-term use (6). After treatment of $\beta$ receptor blockers, the increase of $\beta$ receptor is regarded as the possible mechanism of improvement for specific $\beta$ receptor blocker medications such as metoprolol (1). This increase occurs much earlier than the improvement of clinical symptoms. For some $\beta$ receptor blocker medications, such as carvedilol and bucindolol, there is no increase in $\beta$ receptors following treatment but obvious clinical benefits occur (3). In addition, the increase of $\beta$ receptors increases the sensitivity of cardiac muscle cells to sympathetic nerve stimulation, which may actually be detrimental. Currently, a selective $\beta 1$-AR blocker has been used in the treatment of patients with heart failure and findings have shown that it also increases $\beta 2-A R$ (7). If this is the case the effects of selective $\beta 1-A R$ blockers on cardiac muscle cells in heart failure remain to be determined. 
Previous findings showed that the amount of activity of the calcium pump sarcoplasmic reticulum $\mathrm{Ca}^{2+}$-ATPase (SERCA2a) in the sarcoplasmic reticulum during heart failure was decreased (8-10). This decrease in activity affected the contraction and relaxation of cardiac muscle. A large number of experiments demonstrate that SERCA2a activity during heart failure is $30 \%$ lower than normal (11). Furthermore, contractility increases with enhanced SERCA2a activity as in vitro experiments of cardiac muscle in heart failure indicate $(12,13)$. Previous studies examining the mechanism of $\beta$ receptor blockers and renin-angiotensin system inhibitors on heart failure identified that the amount of activity of SERCA2a increased with the improvement of heart failure symptoms $(14,15)$, indicating that SERCA2a is important in heart failure. Therefore, $\beta 2$-AR blockers potentially influence the systolic function of cardiac muscle cells through the regulation of SERCA2a.

The aim of the study was to determine the effects of the highly selective $\beta 2$-AR blocker ICI 118,551 on systolic function and proteins of individual cardiac muscle cells in normal rats and rats with heart failure. Additionally, the underlying molecular mechanism of the $\beta 2$-AR blocker on cells was examined. Influences of systemic factors including nerve and body fluid were excluded.

\section{Materials and methods}

Experimental animals. In total, 250 male Sprague-Dawley rats weighing 180-220 g were provided by the Experimental Animal Center of Xuzhou Medical College (Jiangsu, China).

The study was approved by the ethics committee of Xuzhou Medical College.

Instruments and reagents. Collagenase II was purchased from Worthington Biochemical Corp. (Freehold, NJ, USA). ICI 118,551 , a $\beta 2$ selective blocker, was purchased from Sigma-Aldrich (St. Louis, MO, USA), and required storage in the dark. The SDS-PAGE gel development kit was purchased from Beyotime Institute of Biotechnology (Jiangsu, China). Molecular weight marker, anti-mouse IgG and anti-rabbit IgG were purchased from Sigma-Aldrich. Anti- $\beta$-actin was purchased from Cell Signaling Technology, Inc. (Danvers, MA, USA); anti- $32-A R$ (H-20): sc-569 was obtained from Santa Cruz Biotechnology, Inc. (Santa Cruz, CA, USA). The NBT/BCIP alkaline phosphatase color development kit was purchased from Promega Corp. (Madison, WI, USA) and the protease inhibitor cocktail set was purchased from Merck Millipore (Darmstadt, Germany). Anti-SERCA2a monoclonal antibody was purchased from Sigma-Aldrich, Langendorff cardiac muscle cell perfusion apparatus and the dynamic boundary detection system of individual cells were obtained from IonOptix (Westwood, MA, USA). Gel electrophoresis system and semi-dry electrophoretic transfer system were purchased from Bio-Rad Laboratories, Inc. (Hercules, CA, USA). The discolored shaking table was obtained from Taicang. Statistical analysis software used was ImageJ, SigmaStat and SigmaPlot.

Establishment of heart failure model for rats. Abdominal aortic constriction was performed to prepare the model of a rat with heart failure. Briefly, male Sprague-Dawley rats were weighed and anesthetized. After exposing the internal structures, an in-house no. 7 silver clip was used as banding along with aorta abdominalis over renal arteries with a diameter of $0.7 \mathrm{~mm}$. For the sham group, the aorta abdominalis was separated without banding, and then closed. Twelve weeks after the operation, multi-functional diagnostic ultrasound determined intra-cardiac structure and function using a $10 \mathrm{~S}$ probe at a frequency of $11.0 \mathrm{MHz}$. The M-type ultrasound recorded contraction and relaxation change curves of the left ventricle at the anterior and posterior leaflet levels of the bicuspid valve to test LVEDD, LVESD, FS and EF.

Separation, cultivation and calculation of survival rate for cardiac muscle cells. A Sprague-Dawley rat was anesthetized and an incision was made. The heart was removed and placed into cold $1 \mathrm{mM} / 1$ calcic $\mathrm{KH}$ solution for cardiac arrest. The heart was hung on a Langendorff constant flow perfusion apparatus immediately after arrest and then perfused with $1 \mathrm{mM} / 1$ calcic KH solution, low calcium solution and enzyme solution, respectively. The heart was removed while soft, sectioned into pieces, and the sections were centrifuged at $400 \mathrm{x} g$ for $1 \mathrm{~min}$. The supernatant was then discarded. The material was placed in $1 \mathrm{mM} / 1$ calcic $\mathrm{KH}$ solution, and allowed to settle naturally after re-suspension. This was repeated three times and then allowed to settle at a room temperature of $32^{\circ} \mathrm{C}$. After natural settlement, the solution was changed. Visual counting was used to calculate cell density. Cardiac muscle cell suspension liquid $(1 \mathrm{ml})$ was added into one well of a 24 -well plate. Under a 10X objective lens five viewpoints were selected and the total amount of rhabdocytes was calculated. The total amount of cells and survival rate in these five viewpoints were then calculated. Subsequently, the cells were cultivated in serum-free medium for $48 \mathrm{~h}$ (at $37^{\circ} \mathrm{C}$ in a $5 \% \mathrm{CO}_{2}$ incubator). The survival rate was calculated by random selection of five viewpoints from three groups of Petri dishes. Images were captured under $10 \mathrm{X}$ objective lens and marked to calculate the rod-shape rate following cultivation for $48 \mathrm{~h}$. The percentage of surviving cells was calculated as (amount of rod-shaped cell/amount of total cells) $\times 100 \%$.

Experimental group and administration methods. The heart failure model comprised 75 rats with heart failure and 70 rats in the Sham group. Cardiac muscle cells of adult rats from primary culture were divided into the Sham, HF and $\mathrm{HF}+\mathrm{ICI} 50 \mathrm{nM}$ groups. Indicators were observed after cultivation for $>48 \mathrm{~h}$.

Testing of systolic function of individual cardiac muscle cells. A dynamic boundary detection system was used for individual cells (IonOptix) to record the length-time change curve of cardiac muscle cells. Cardiac muscle cells in each group were cultivated for $>48 \mathrm{~h}$ and then washed with $\mathrm{KH}$ solution three times. Cell suspension was placed into perfusion to test systolic function. After standing for $5 \mathrm{~min}$, the cell suspension was perfused using $1 \mathrm{mM} / 1$ calcic $\mathrm{KH}$ solution with $5 \% \mathrm{CO}_{2}$ mixed oxygen. Cardiac muscle cells were stimulated with electricity $(0.5 \mathrm{~Hz})$. The liquid flow rate was $1.5 \mathrm{ml} / \mathrm{min}$ and the ISO concentration response curve accumulated through semi-log increments, ceasing 
when maximum contraction was reached or an arrhythmia occurred. Rod-shaped cardiac muscle cells with clear transverse striation, complete cell membrane and steady contraction were selected to record the contraction curve. The data were analyzed using IonWizard software (IonOptix Corp., Milton, MA, USA) with the following results obtained: shortened rate of cardiac muscle cell [(initial length of cell length of cell after contraction)/initial length of cell x 100\%], time-to-peak (TTP) and R50. When testing the systolic function of cardiac muscle cells, newly prepared isoprenaline (10-7 mol/1, away from light) was added into the circulated $\mathrm{KH}$ solution to observe the response of cells to isoprenaline.

Western blot analysis and immunoprecipitation. To prepare cell samples, cardiac muscle cells were collected and cultivated for $>48 \mathrm{~h}$, washed twice, centrifuged and the supernatant discarded. Homogenate with a protease inhibitor cocktail was added and cells disintegrated through ultrasonification. These cells were preserved at $-80^{\circ} \mathrm{C}$. The Lowry method was used as a reference to test protein content with BSA as the standard protein. To extract membrane protein, cardiac muscle cell samples were preserved at $-80^{\circ} \mathrm{C}$, and placed in an ice box for thawing, centrifuged for $5 \mathrm{~min}$ at $14,000 \times \mathrm{g}$ and the supernatant was discarded. Cell lysis buffer $0.3 \%$ Triton X-100 x 100/PBS (mixed with protease inhibitor) was added and blended with a micropipette (Gilson, Villiers Le bel, France). The weight was 14,000 g. Centrifugation followed for $15 \mathrm{~min}$. The supernatant was the cytoplasm layer, and the subnatant the cytomembrane layer. The cytomembrane layer was drained and placed into $1.5 \mathrm{ml}$ EP for further experimentation.

For western blot analysis, all the following steps occurred at $4{ }^{\circ} \mathrm{C}$. The samples were placed with the same protein content into $4 \mathrm{X}$ Laemmli SDS-PAGE loading buffer of the same volume and then in a boiling water bath for $5 \mathrm{~min}$ for degeneration treatment. Denatured protein samples of equal amount $(100 \mu \mathrm{g})$ were removed, separated through SDS-PAGE and then transferred to NC membrane through a semi-dry electrophoretic transfer method. The NC membrane was placed into a confining liquid and incubated at room temperature for $3 \mathrm{~h}$. Primary mouse anti-serca2 ATPase monoclonal antibody (Sigma, catalog no.: s1439) was added at a dilution of 1:1000 and incubated at room temperature for $4 \mathrm{~h}$ at $4^{\circ} \mathrm{C}$ overnight. The membrane was washed with TBST (5 min $x$ 3) and a secondary antibody marked with AP was added. The membrane was incubated at room temperature for $2 \mathrm{~h}$, washed with TBST (5 min x 3) and then rinsed with water. A NBT/BCIP kit was used for color development in new AP coloring solution and the reaction was terminated using running water. Image processing apparatus was used in the analysis (to observe the expression and activation of protein).

Immunoprecipitation occurred at $4^{\circ} \mathrm{C}$. Briefly, a volume 5 -fold that of the IP buffer solution was added to the samples with the same protein content $(400 \mu \mathrm{g})$. Then, $25 \mu \mathrm{l}$ protein A/G-agarose was used in pre-adsorption for $1 \mathrm{~h}$, and centrifuged at $1,000 \mathrm{x} \mathrm{g}$ for $2 \mathrm{~min}$. The supernatant was discarded and 1-2 $\mu \mathrm{g}$ antibody was added, which was allowed to react on a rotating vortex mixer for $4 \mathrm{~h}$ or overnight. Subsequently, $25 \mu 1$ protein $\mathrm{A} / \mathrm{G}$-agarose was added and allowed to react
Table I. Selection of rats with heart failure by cardiac function test through ultrasonic cardiogram.

Models of heart failure rats

Test

Preoperative Post-operative 12 weeks

\begin{tabular}{lrr}
\hline LVDd $(\mathrm{mm})$ & $5.02 \pm 0.84$ & $5.46 \pm 0.64^{\mathrm{a}}$ \\
LVDs $(\mathrm{mm})$ & $2.89 \pm 0.32$ & $3.87 \pm 0.37^{\mathrm{a}}$ \\
FS $(\%)$ & $42.64 \pm 1.94$ & $28.17 \pm 1.47^{\mathrm{a}}$ \\
EF $(\%)$ & $80.05 \pm 3.62$ & $62.07 \pm 5.15^{\mathrm{a}}$ \\
\hline
\end{tabular}

Means $\pm \mathrm{SD}, \mathrm{n}=70 .{ }^{\mathrm{a}} \mathrm{P}<0.05$.

on a rotating vortex mixer for $2 \mathrm{~h}$. The agarose weighed $10.00 \mathrm{~g}$. Following the reaction the agarose was centrifuged at $1,000 \mathrm{x} \mathrm{g}$ for $2 \mathrm{~min}$, and washed with IP buffer solution three times. Subsequently, 2X Laemmli SDS-PAGE loading buffer of the same volume was added, mixed and placed into a boiling water bath for $5 \mathrm{~min}$ to elute protein from agarose, this weighed $10.00 \mathrm{~g}$. This was centrifuged at $1,000 \mathrm{x} \mathrm{g}$ for $2 \mathrm{~min}$, and the supernatant was absorbed for immunoprecipitation.

Western blot analysis. Ten percent separation gel and 4\% spacer gel were used to perform SDS-PAGE. After separation, the bands on the gel were transferred to an NC membrane using a semi-dry electrophoretic transfer method. The NC membrane was placed into confining liquid and incubated at room temperature for $3 \mathrm{~h}$. Primary antibody $(1: 1,000)$ was added and incubated at room temperature for $4 \mathrm{~h}$. Then, secondary antibody $(1: 10,000)$ was added and incubated at room temperature for $2 \mathrm{~h}$. TBST was then used to wash the membrane (5 min x 3). An NBT/BCIP kit was used for color development in a new AP coloring solution and the reaction was terminated using running water. Coloring bands on the membrane were scanned, processed and analyzed through software such as ImageJ, SigmaStat and SigmaPlot. Optical density in the bands was expressed by the multiple of the normal group on the same membrane.

Statistical analysis. SPSS 16.0 software (Chicago, IL, USA) was used to analyze data. Data were presented as mean \pm SD. Comparison among groups were analyzed through ANOVA and comparison between groups tested by q. $\mathrm{P}<0.05$ indicated statistically significant results.

\section{Results}

Identification results of heart failure model for rats. After 8 weeks of an established heart failure model, symptoms such as decreased appetite, low spirits, no luster in fur, fluffy fur and polypnea during a resting state occurred. No such changes were observed in the Sham group during the same period. Related parameters in ultrasonic cardiogram testing 12 weeks after the operation in the heart failure model group indicated that the inner diameters of the atrium and ventricle were increased, myocardium was thinner and EF was significantly decreased (Table I). Other objective evidence for heart failure was based on $\mathrm{EF}<64 \%$ in the ultrasonic cardiogram. 

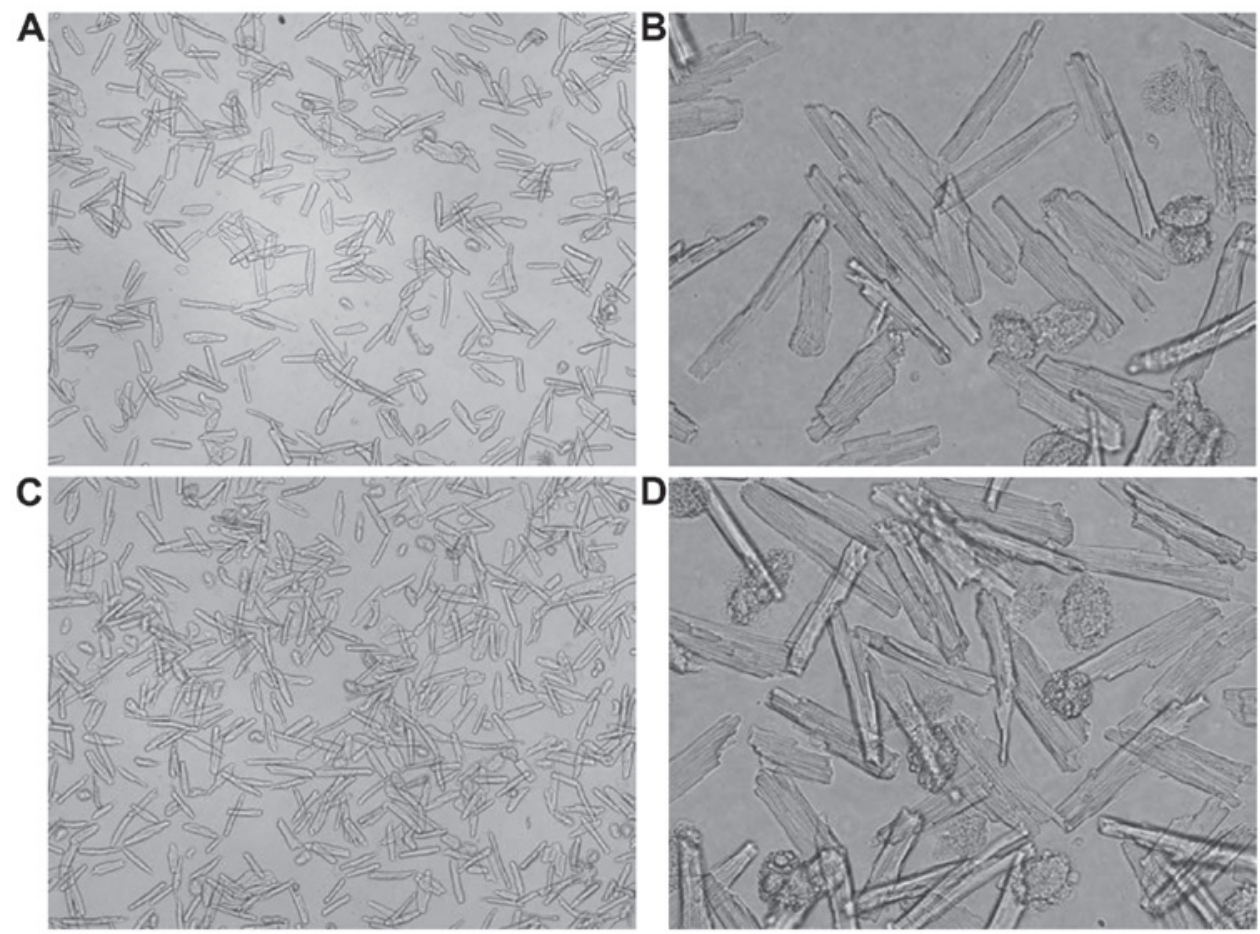

Figure 1. (A) Immediately isolated cardiac muscle cells of rats with heart failure (x40). (B) Cardiac muscle cells with heart failure cultivated for $48 \mathrm{~h}$ (x200). (C) Immediately isolated cardiac muscle cells of normal rats (x40). (D) Normal cardiac muscle cells cultivated for $48 \mathrm{~h}$ (x200).

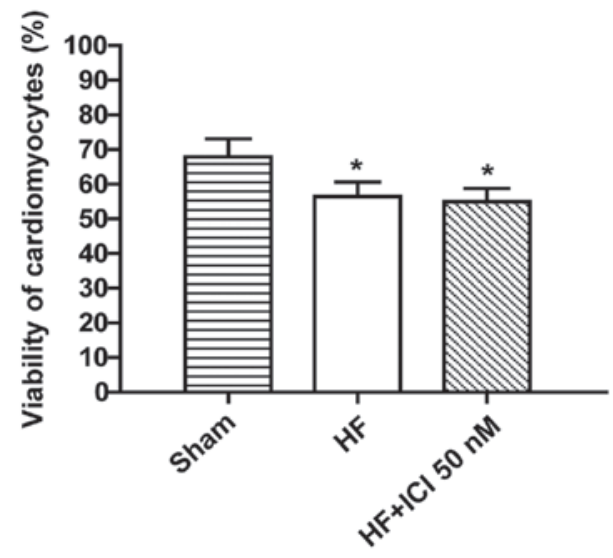

Figure 2. The survival rate of cardiac muscle cells. Compared with the Sham group, ${ }^{\mathrm{P}}<0.05$ in group HF and $\mathrm{HF}+\mathrm{ICI} 50 \mathrm{nM}$. HF, heart failure.

Survival rate of cardiac muscle cell of rats with heart failure. Compared with the Sham group, the survival rates of cardiac muscle cells in group $\mathrm{HF}$ and $\mathrm{HF}+\mathrm{ICI} 50 \mathrm{nM}$ were decreased $(\mathrm{P}<0.05)$. No such changes were identified in terms of the survival rate of cardiac muscle cells in group HF+ICI $50 \mathrm{nM}$ compared with group HF $(\mathrm{P}>0.05)$ (Figs. 1 and 2$)$.

Molecular biology results for rats with heart failure. Compared with the Sham group, Gi protein expression levels in group $\mathrm{HF}$ and $\mathrm{HF}+\mathrm{ICI} 50 \mathrm{nM}$ increased $(\mathrm{P}<0.05)$, whereas Gs protein expression $(\mathrm{P}<0.05)$ and SERCA2a protein expression $(\mathrm{P}<0.05)$ decreased. Compared with group HF, there were no obvious differences in terms of $\beta 2$-AR protein and Gs protein expression amounts for cardiac muscle cells in group
$\mathrm{HF}+\mathrm{ICI} 50 \mathrm{nM}(\mathrm{P}>0.05)$. Gi protein expression increased $(\mathrm{P}<0.05)$ but the SERCA2a protein expression amount was obviously decreased $(\mathrm{P}<0.05)$ (Fig. 3).

Systolic function test results of cardiac muscle cells of rats with heart failure. Compared with the Sham group, the basic contraction $\left(1 \mathrm{mM} \mathrm{Ca}{ }^{2+}\right)$ amplitude percentage of cardiac muscle cells in group HF significantly decreased $(4.761 \pm 1.103$ vs. $3.140 \pm 1.904 \%, \mathrm{n}=220, \mathrm{P}<0.01)$. In addition, the basic contraction $\left(1 \mathrm{mM} \mathrm{Ca}{ }^{2+}\right)$ amplitude percentage of cardiac muscle cells in group HF significantly decreased $(4.761 \pm 1.103$ vs. $2.761 \pm 1.110 \%, \mathrm{n}=220, \mathrm{P}<0.01)$. Compared with group HF, the basic contraction $\left(1 \mathrm{mM} \mathrm{Ca}^{2+}\right)$ amplitude percentage of cardiac muscle cells in group HF+ICI $50 \mathrm{nM}$ decreased (3.140 \pm 1.094 vs. $2.761 \pm 1.110 \%, \mathrm{P}<0.05$ ) (Fig. 4).

Compared with the Sham group, TTP contraction in group HF was shortened $(0.229 \pm 0.021$ vs. $0.207 \pm 0.014 \mathrm{sec}, \mathrm{n}=60$, $\mathrm{P}<0.05)$ as was the TTP 50\% relaxation (R50) of cardiac muscle cells $(0.291 \pm 0.031$ vs. $0.264 \pm 0.027 \mathrm{sec}, \mathrm{n}=60, \mathrm{P}<0.05)$. Additionally, TTP contraction in group HF+ICI $50 \mathrm{nM}$ was shortened $(0.229 \pm 0.021$ vs. $0.198 \pm 0.018 \mathrm{sec}, \mathrm{n}=60, \mathrm{P}<0.05)$ as was the TTP 50\% relaxation (R50) of cardiac muscle cells ( $0.291 \pm 0.031$ vs. $0.258 \pm 0.024 \mathrm{sec}, \mathrm{n}=60, \mathrm{P}<0.05)$. There were no obvious differences regarding R50 and R90 between heart failure cells $(\mathrm{P}>0.05)$. Compared with group HF, TTP in group $\mathrm{HF}+\mathrm{ICI} 50 \mathrm{nM}$ decreased $(\mathrm{P}<0.05)$ (Fig. 5).

Following the stimulation of $\mathrm{Ca}^{2+}$, the maximum contraction amplitude percentage of the cardiac muscle cell in group HF decreased $(17.664 \pm 3.683$ vs. $16.821 \pm 4.104 \%, n=60$, $\mathrm{P}<0.05)$ when compared with the Sham group, as did that of group $\mathrm{HF}+\mathrm{ICI} 50 \mathrm{nM}(17.664 \pm 3.683$ vs. $14.670 \pm 4.021 \%$, $\mathrm{n}=60, \mathrm{P}<0.05)$. The maximum contraction amplitude percentage of cardiac muscle cells in group $\mathrm{HF}+\mathrm{ICI} 50 \mathrm{nM}$ 

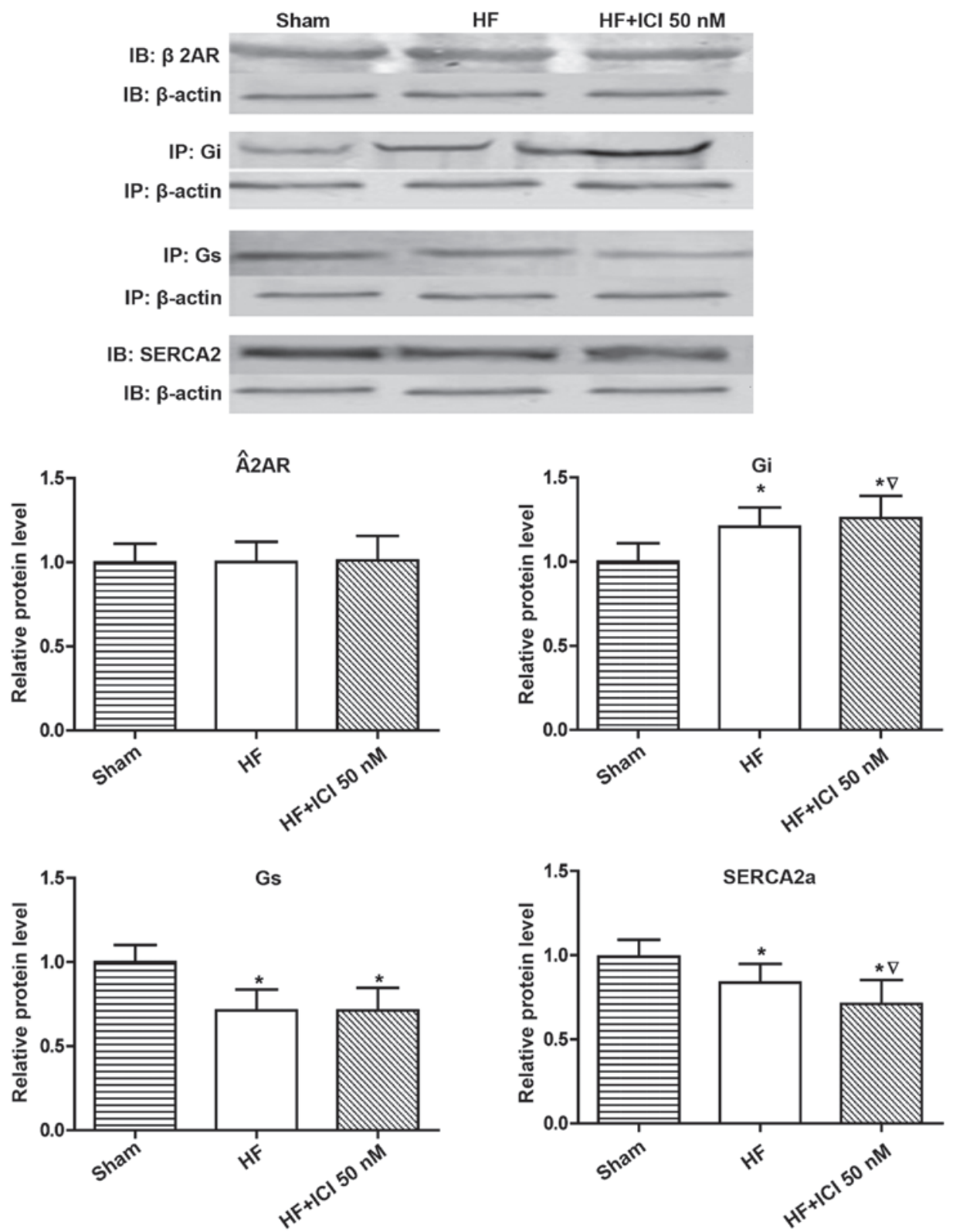

Figure 3. Protein expression of $\beta 2-\mathrm{AR}, \mathrm{Gi}$, Gs and SERCA2a of rats with heart failure in the various groups. Compared with the Sham group, ${ }^{*} \mathrm{P}<0.05$; compared with group $\mathrm{HF},{ }^{\triangleright} \mathrm{P}<0.05$. $\beta 2$-AR, $\beta 2$-adrenergic receptor; SERCA2a, sarcoplasmic reticulum $\mathrm{Ca}^{2+}$-ATPase; $\mathrm{HF}$, heart failure.

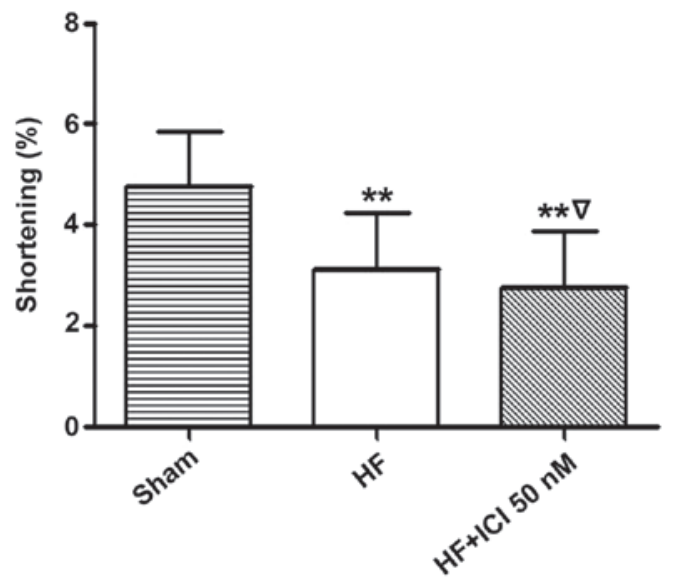

Figure 4. Basic contraction of cardiac muscle cells of rats with heart failure in the studied groups. Compared with the Sham group, ${ }^{* *} \mathrm{P}<0.01$; compared with group $\mathrm{HF},{ }^{\circ} \mathrm{P}<0.05$. HF, heart failure. was reduced compared with that in group HF $(16.821 \pm 4.104$ vs. $14.670 \pm 4.021 \%, \mathrm{P}<0.05$ ) (Fig. 6).

Following the stimulation of ISO, the maximum contraction amplitude percentage of cardiac muscle cells in group $\mathrm{HF}$ decreased $(18.757 \pm 3.051$ vs. $16.587 \pm 3.075 \%, \mathrm{n}=60, \mathrm{P}<0.05)$ when compared with the Sham group, as was the case for group $\mathrm{HF}+\mathrm{ICI} 50 \mathrm{nM}(18.757 \pm 3.051$ vs. $15.384 \pm 3.112 \%, \mathrm{n}=60$, $\mathrm{P}<0.05)$. The maximum contraction amplitude percentage of cardiac muscle cells in group $\mathrm{HF}+\mathrm{ICI} 50 \mathrm{nM}$ was lower than that in group HF $(16.587 \pm 3.075$ vs. $15.384 \pm 3.112 \%$, $\mathrm{P}<0.05$ ) (Fig. 7).

\section{Discussion}

$\mathrm{CHF}$ is a common clinical syndrome that remains an important lethal cardiovascular disease. The application of $\beta$-AR blocker in the long-term treatment of heart failure has changed 

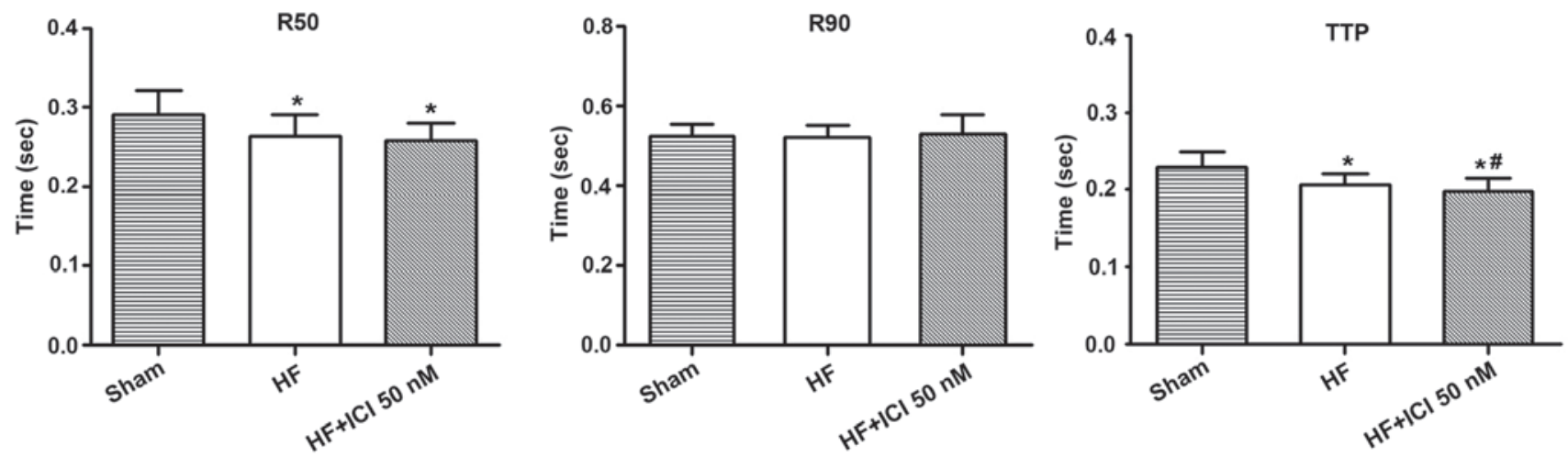

Figure 5. Contraction of cardiac muscle cells of rats with heart failure at R50, R90 and TTP. Compared with the Sham group, "P $<0.05$; compared with group $\mathrm{HF},{ }^{\text {"P }}<0.05$. TTP, time-to-peak; HF, heart failure.
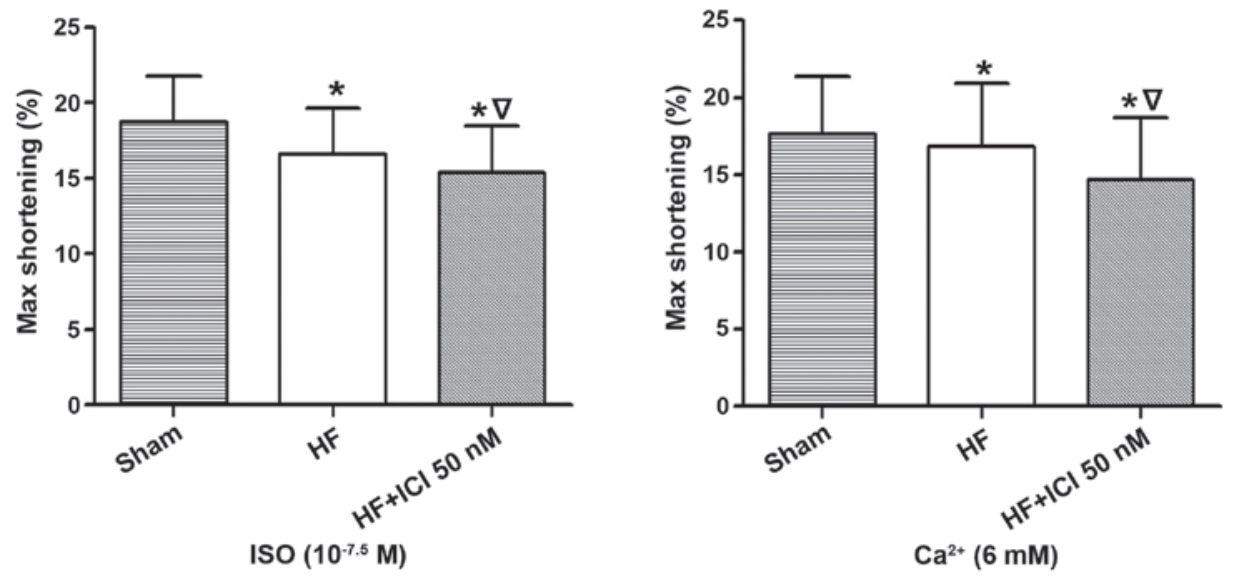

Figure 6. Maximum contraction of cardiac muscle cells of rats with heart failure in the studied groups. Compared with the Sham group, "P<0.05; compared with group $\mathrm{HF},{ }^{\triangleright} \mathrm{P}<0.05$. HF, heart failure.
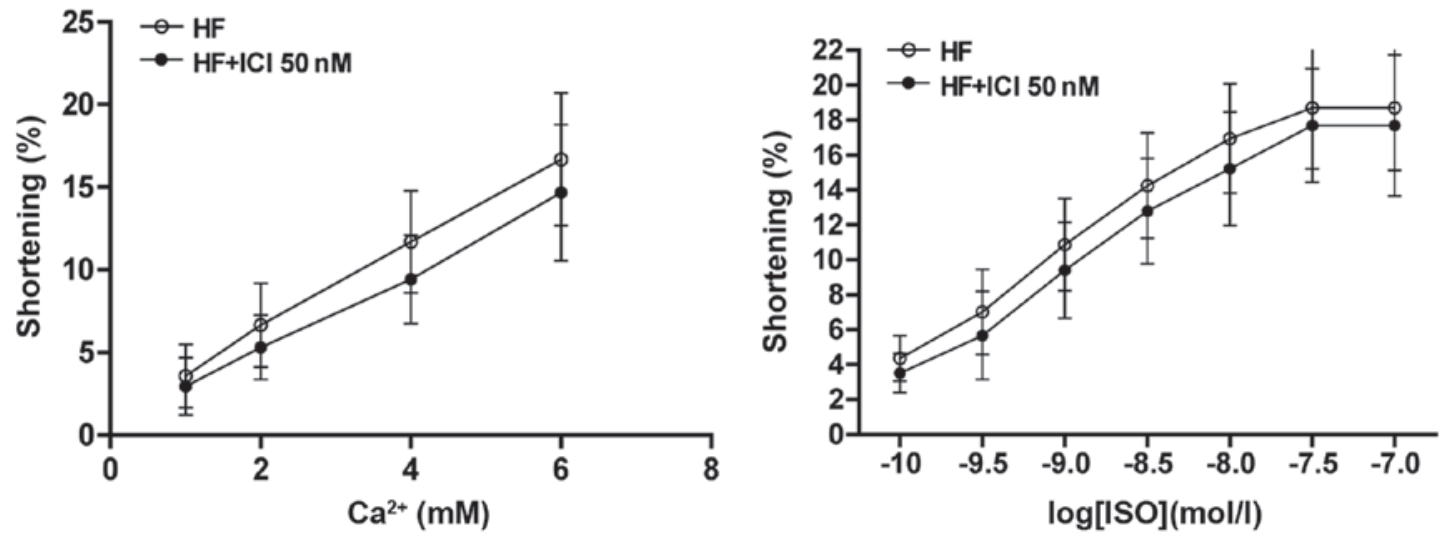

Figure 7. Reaction curve of cardiac muscle cells of rats with heart failure (HF) to $\mathrm{Ca}^{2+}$ and concentration of ISO.

previous therapeutic schedules. Although it may reduce the contraction ability of cardiac muscle cells over a short period of time, it does increase myocardial contractility or decrease the mortality rate in the long term.

The surface of cardiac muscle cells mainly expresses two ARs, $\beta 1$ and $\beta 2$. Activated $\beta 1$-AR stimulates the classic
Gs-AC-cAMP-PKA signaling pathway (16) and causes a series of phosphorylation of proteins associated with calcium treatment. However, activated $\beta 2-\mathrm{AR}$, not only stimulates the abovementioned pathway and generates positive contraction and relaxation effects, but also activates the Gi-PI3K-AKt signaling pathway (17), limiting and balancing 
out positive relaxation and contraction effects generated by the Gs signaling pathway in terms of space and function. It is considered that there are no changes regarding the expression of $\beta 2-A R$ in heart failure (18). The results of the present study show that compared with the Sham group, there were no changes in the expression of $\beta 2-\mathrm{AR}$ of cardiac muscle in group HF. By contrast, Gs protein was decreased, Gi protein was increased and SERCA2a protein expression was decreased. Function testing of cardiac muscle indicates that basic contraction during heart failure decreases, because of decreasing $\beta 1-A R$. Therefore, the contraction effect generated from coupling with Gs decreases and the function of cardiac muscle is reduced.

The effects of systemic factors such as nerve and body fluid were excluded from the present study, which identified the effects of highly selective $\beta 2$-AR blocker ICI 118,551 on systolic function and the protein of individual cardiac muscle cells of normal rats, as well as rats with heart failure based directly on cell and receptor level. The results show that ICI 118,551 may decrease the systolic function of cardiac muscle in isolated heart failure under basic contraction and the stimulation of $\mathrm{Ca}^{2+}$ and ISO.

The present findings have shown that when the concentration of $\mathrm{Ca}^{2+}$ is $>6 \mathrm{mM}$, cardiac muscle in heart failure begins to spasm, decreasing the function of individual cardiac muscle cells. When stimulating cardiac muscle with ISO of different concentrations, the contraction amplitude of cardiac muscle in heart failure may increase with the increased concentration of ISO and be lower than the contraction amplitude of normal cardiac muscle cell under the same concentration. This finding shows that compared with the normal cardiac muscle, the reactiveness to catecholamines of cardiac muscle in heart failure is lowered. According to literature (19), cardiac muscle tissues exposed to an epinephrine agonist over a long period of time die easily. This may be associated with the decreasing concentration of Ca ATPase protein in the sarcoplasmic reticulum with myocardial hypertrophy and heart failure (20). Following the development of myocardial hypertrophy, the reduction becomes more obvious and results in the dysfunction of $\mathrm{Ca}^{2+}$ intake. In addition, due to long-term sympathetic nerve stimulation, cardiac muscle becomes hypertrophic and oxygen consumption of myocardium increases, and the resulting insufficient energy supply affects the systolic function of cardiac muscle $(21,22)$.

Compared with the HF control group, systolic function in the ICI 118,551 (50 nM) HF group decreased, Gi protein expression increased and SERCA2a protein level decreased. Thus, a negative inotropic effect occurs for ICI 118,551 through the Gi-PI3K-AKt signaling pathway. This increases Gi protein on the one hand, whereas, the systolic function of cardiac muscle cells may be reduced by decreasing SERCA2a pump function on intake, storage and release of $\mathrm{Ca}^{2+}$. The survival rate of cardiac muscle in heart failure is lower than that of normal hearts (19). ICI 118,551 has no effect on the survival rate of cardiac muscle cells in heart failure, which ensures that there are no differences in terms of cell amount between groups. A large number of data have shown that loss of cardiac muscle cells may be a key factor for the development of heart failure (23). Cardiac muscle cell apoptosis is the main reason for the continuous loss of myocardial contraction units during the development of CHF. This is because of the progressive decrease of cardiac function involved in the physiopathologic changes occurring during $\mathrm{CHF}$.

\section{Acknowledgements}

The study was partly financed by the Jiangsu Provincial Special Program of Medical Science (BL2012019).

\section{References}

1. Dzimiri N: Regulation of $\beta$-adrenoceptor signaling in cardiac function and disease. Pharmacol Rev 51: 465-501, 1999.

2. Xiao RP and Lakatta EG: Beta 1-adrenoceptor stimulation and beta 2 -adrenoceptor stimulation differ in their effects on contraction, cytosolic $\mathrm{Ca}^{2+}$, and $\mathrm{Ca}^{2+}$ current in single rat ventricular cells. Circ Res 73: 286-300, 1993.

3. Zheng M, Han QD and Xiao RP: Distinct $\beta$-adrenergic receptor subtype signaling in the heart and their pathophysiological relevance. Sheng Li Xue Bao 56: 1-15, 2004.

4. Bristow MR, Ginsburg R, Umans V, Fowler M, Minobe W, Rasmussen R, Zera P, Menlove R, Shah P and Jamieson S: Beta 1- and beta 2-adrenergic-receptor subpopulations in nonfailing and failing human ventricular myocardium: coupling of both receptor subtypes to muscle contraction and selective beta 1-receptor down-regulation in heart failure. Circ Res 59: 297-309, 1986.

5. Kiuchi K, Shannon RP, Komamura K, Cohen DJ, Bianchi C, Homcy CJ, Vatner SF and Vatner DE: Myocardial beta-adrenergic receptor function during the development of pacing-induced heart failure. J Clin Invest 91: 907-914, 1993.

6. Lv Z and Huang R: Common issues of neuroendocrine antagonist in treatment of chronic cardiac failure. Chin J Cardiol 33: 293-296, 2005 (In Chinese).

7. Aoyagi T, Yonekura K, Eto Y, Matsumoto A, Yokoyama I, Sugiura S, Momomura S, Hirata Y, Baker DL and Periasamy M: The sarcoplasmic reticulum $\mathrm{Ca}^{2+}$-ATPase (SERCA2) gene promoter activity is decreased in response to severe left ventricular pressure-overload hypertrophy in rat hearts. J Mol Cell Cardiol 31: 919-926, 1999

8. Kögler H, Hartmann O, Leineweber K, Nguyen van P, Schott P, Brodde OE and Hasenfuss G: Mechanical load-dependent regulation of gene expression in monocrotaline-induced right ventricular hypertrophy in the rat. Circ Res 93: 230-237, 2003.

9. Dash R, Frank KF, Carr AN, Moravec CS and Kranias EG: Gender influences on sarcoplasmic reticulum $\mathrm{Ca}^{2+}$-handling in failing human myocardium. J Mol Cell Cardiol 33: 1345-1353, 2001.

10. Spragg DD, Leclercq C, Loghmani M, Faris OP, Tunin RS, DiSilvestre D, McVeigh ER, Tomaselli GF and Kass DA: Regional alterations in protein expression in the dyssynchronous failing heart. Circulation 108: 929-932, 2003.

11. Wei J, Liu HC, Lee FY, Lee MS, Huang CY, Pan HP and Lin CI: Role of the sarcoplasmic reticulum in altered action potential and contraction of myopathic human and hamster ventricle. Clin Exp Pharmacol Physiol 30: 232-241, 2003.

12. Van de Caetsbeek I, Raeymaekers L, Wuytack F and Vangheluwe P: Factors controlling the activity of the SERCA2a pump in the normal and failing heart. Biofactors 35: 484-499, 2009.

13. Sakata Y, Yamamoto K, Mano T, Nishikawa N, Yoshida J, Nakayama H, Otsu K, Suzuki K, Tada M, Hori M, et al: Angiotensin II type 1 receptor blockade prevents diastolic heart failure through modulation of $\mathrm{Ca}(2+)$ regulatory proteins and extracellular matrix. J Hypertens 21: 1737-1745, 2003.

14. Sabbah HN, Sharov VG, Gupta RC, Mishra S, Rastogi S, Undrovinas AI, Chaudhry PA, Todor A, Mishima T, Tanhehco EJ, et al: Reversal of chronic molecular and cellular abnormalities due to heart failure by passive mechanical ventricular containment. Circ Res 93: 1095-1101, 2003.

15. Chinese Society of Cardiology of Chinese Medical Association, Editorial Board of Chinese Journal of Cardiology: Guidelines for the diagnosis and management of chronic heart failure. Chin J Cardiol 35: 1076-1095, 2007. 
16. Brixius K, Frank KF, Bölck B, Hoyer F and Schwinger RH: Reverse remodeling of the intracellular $\mathrm{Ca}(2+)$-homeostasis: new concepts of pathophysiology and therapy of heart failure. Wien Med Wochenschr 156: 209-215, 2006 (In German).

17. Gong H, Adamson DL, Ranu HK, Koch WJ, Heubach JF, Ravens U, Zolk O and Harding SE: The effect of Gi-protein inactivation on basal, and beta(1)- and beta(2)AR-stimulated contraction of myocytes from transgenic mice overexpressing the beta(2)-adrenoceptor. Br J Pharmacol 131: 594-600, 2000.

18. Hamdani N, de Waard M, Messer AE, Boontje NM, Kooij V, van Dijk S, Versteilen A, Lamberts R, Merkus D, Dos Remedios C, et al: Myofilament dysfunction in cardiac disease from mice to men. J Muscle Res Cell Motil 29: 189-201, 2008.

19. Lohse MJ, Engelhardt S and Eschenhagen T: What is the role of beta-adrenergic signaling in heart failure? Circ Res 93: 896-906, 2003.
20. Lee DI, Vahebi S, Tocchetti CG, Barouch LA, Solaro RJ, Takimoto E and Kass DA: PDE5A suppression of acute beta-adrenergic activation requires modulation of myocyte beta-3 signaling coupled to PKG-mediated troponin I phosphorylation. Basic Res Cardiol 105: 337-347, 2010.

21. Tóth A, Kiss L, Varró A and Nánási PP: Potential therapeutic effects of $\mathrm{Na}^{+} / \mathrm{Ca}^{2+}$ exchanger inhibition in cardiac diseases. Curr Med Chem 16: 3294-3321, 2009.

22. Vinge LE, Raake PW and Koch WJ: Gene therapy in heart failure. Circ Res 102: 1458-1470, 2008.

23. Sun H, Zhou F, Wang Y, Zhang Y, Chang A and Chen Q: Effects of beta-adrenoceptors overexpression on cell survival are mediated by $\mathrm{Bax} / \mathrm{Bcl}-2$ pathway in rat cardiac myocytes. Pharmacology 78: 98-104, 2006. 